\title{
What Went Wrong and Why? Nationalism versus Democracy in Eastern and Western Europe
}

\author{
Vladimir Tismaneanu
}

I am writing this on 23 October, the day of the Hungarian Revolution. In Budapest, Viktor Orban delivers a fierce anti-EU speech, denounces the spectre of 'globalism' and demonises George Soros, the Hungarian-American philanthropist. A few days earlier the Parisian daily Le Monde published an article by its Bucharest correspondent about the possibility of a Romanian exit, or 'Roexit'. The thesis of my contribution is that Brexit opened the gate for this wave of authoritarian xenophobia in the countries of the former Soviet Bloc.

The purpose of this analysis is to identify the origins of the bizarre unhappiness that has descended onto Western populations who should be enjoying the freedom and prosperity which liberal democracy has brought them. I will consider some of the main threats to post-communist liberal democracies, especially the perils related to the weakness of pluralist traditions, institutions and values, and the rise of movements and ideologies rooted in cultural and political malaise, ressentiment and disaffection. It is not my purpose to put forward apocalyptic scenarios. Instead, I shall suggest a diagnosis of the main vulnerabilities of Eastern Europe's postcommunist states connected to the rise and affirmation of ethnocratic parties and movements.

These explosions of authoritarianism in post-communist Central and Eastern Europe have much to do with Brexit. Firstly and unequivocally, the West should care about the East. Whenever we ignore perils elsewhere, they eventually arrive on our doorstep. Nobody is immune: as has been said for a long time, either the Balkans Westernise or the West Balkanises. Secondly, we are mystified by how people in democracies are willing to risk it all. And we remain horrified that so many people have decided that they don't care for, and in fact despise, open societies. We can find some answers to our puzzle by examining the East. We have to acknowledge the disappointing reality, which is the first step to countering the far-right's momentum, a reality that made Brexit possible.

If Central and Eastern European societies can courageously, if barely, emerge from a most repugnant, enduring, and cruel system of politics and social organisation, immediately realise democracy and freedom and then quickly turn their backs on what they had been deprived of and craved for so long, we can be sure that the domestic nationalist threat to democracy is real. Eastern Europe is willing to risk all the amazing progress which it has achieved in the last couple of decades to pursue ideas and ways of thinking which fascists and communists (the latter in living memory for all but the youngest generation) had used to wreck human life and civilisation in every corner of their lands. Understanding why so much of Central and Eastern Europe is choosing ethnocentric radicalism and xenophobic rage allows us to see clearly how the totalitarian temptation is never securely subjugated to the democratic responsibility.

No society remains loyal to democracy by default, even when it should remember what freedom offers and what ideological illusions bestow. Post-communist Europeans have witnessed the peaks of both utopian experiments and democratic commitments: Soviet absurdity and terror, and Western liberty and prosperity. That they still are willing to make such terrible choices, when so well-informed, shows us that we can make no assumptions about the future. People are restless. Western populations that did not have to pay for poor ideological choices in 
the recent past can easily succumb to self-glorifying populist delusions. If we could see exactly from where these anxieties in the East are coming, then we could consider the follies that are haunting the West and how we can possibly address them.

When I first recognised these risks to the new democracies in Eastern Europe, I was treated like a gloomy voice, a spoiler. After all, the wall was down. How could one not celebrate? The revolutions, the mass protests on the streets which brought down communist imperialism in the eastern half of the continent, were explicitly in the name of freedom and democracy. Now, it seemed, even if one disagreed with Francis Fukuyama, that democracy had arrived, and why would it ever leave? Who could ever want anything else?

But writing in 1992 I felt that the legacies of the past were strong. Not just institutionally, but culturally and socially, people were still steeped in coercive ideological persuasion. They believed in myths, demanded utopia, mobilised for victory, even at the price of diversity and tolerance, reason and law. Even more relevant for what we are seeing in the West and the United Kingdom today are my concerns that any society will struggle to stay liberal indefinitely, whether it exists after seventy years of Leninism or two hundred years of democracy. Some people will always be annoyed with debate, the messy reform of pluralism and the stability of prosperity, and eventually many will find and demand a new politics. We have seen this before and we may see it again. In other words, redemptive politics is not irrevocably over.

I would like to use my own work to trace the elation as well as the disillusionment with liberal democracy that I observed in the East. In 1992 I published Reinventing Politics: Eastern Europe from Stalin to Havel. The title alone demonstrates that I, too, was euphoric. I believed that the demonic dictator had been replaced by the melancholy playwright. One system arrived through invasions, the other through peaceful protests. Yet my book ended with a rather brief warning that demons are not so easily killed, especially those that live in the hearts of common, free citizens. Despite all euphoria, democracy was hard to institutionalise and even harder to make popular.

Throughout the 1990s I could not get rid of my anxiety. While the EU and NATO expanded or prepared to welcome their long-lost European brothers and sisters, and while democracy functioned almost perfectly well, marginal movements of hate, right and left, stubbornly existed. And I believed that these movements had the potential to capture the hearts of a much larger portion of the population, the very same people who were at the moment happily engaged in democracy (or so it seemed, so we all thought, so maybe even they themselves believed). In the mid 1990s I wrote Fantasies of Salvation: Democracy, Nationalism, and Myth in Eastern Europe. I believed that myths of ancestors, of celestial greatness and perfidious enemies, which necessitated a politics of authoritarianism and even war, remained a real option for the fate of Eastern Europe. I worried that exclusionary thoughts could prove to be a smashing success in genuine popularity although they belong in an insane asylum.

Eastern Europe was waiting for Perón. (I mean Juan Domingo Perón, the Argentine populist mountebank.) Anyone who would promise everything to everyone, could one day find a surprising quantity and quality of enthusiastic, even rabid, and certainly blind, support. Myths are simply more successful than rational arguments, because utopian satisfaction - the feeling of righteousness - is more appealing to people than the moral responsibility to unconditionally uphold and defend human rights.

I was sure that whatever would happen would be tied to the communist, and even fascist, past. The same fascist-style movements could emerge in Western Europe, and I wrote about these movements in Fantasies of Salvation. These fantasies would rest on different foundations and find different raw materials, insecurities of society and vulnerabilities of culture. Just like neo-fascism in Eastern Europe, an updated version of fascism could appear in the West. It could happen in Western Europe, too, because these eruptions are not logical or ordained, but simply tied to the human character, at least in mass democratic societies. They are related to the 
temptation to abandon empathy in exchange for pride and to what Erich Fromm identified in the 1930 s as the fear of freedom.

Let me briefly explain what has been happening in Eastern Europe, which is likely to have a major impact on the European Union. Most of the pessimistic forecasts uttered in the aftermath of Leninism's collapse in East Central Europe and the former Soviet Union have not come true. But neither has the best case scenario unfolded. Our hopes, too, have proven to be fantasies. Thus, understanding the post-communist political and cultural situation, including persistent isolationist, anti-globalisation, populist and nationalist trends (including those in countries already part of EU like the Czech Republic, Hungary and Poland), remains of critical importance. We have to consider the importance of political-cultural traditions in the shaping of the new democratic communities: some of these countries have more of a usable liberal-constitutional past than others. This explains the size and success of the role played by civil society in the democratic transitions. Whatever the self-idealising rhetoric of local cultural elites may claim, some of these societies have a long record of illiberal, anti-modern, often xenophobic and exclusive behaviour. The appeals to a pre-communist Central European identity that would be based on tolerance, civility and trust, as opposed to the collectivistic-authoritarian model imposed by Sovietism, tends to neglect the heterogeneous nature of these political cultures, in which democratic and non-democratic, pro-Western and anti-Western, modern and traditionalist values and discourses have long competed with each other.

There always were many disturbing factors in post-communist politics, including a decline of moral standards and a demobilisation of civil society. For two decades they seemed benign, or at least subverted by the dominant allegiance to democracy. Democratic institutions (especially the party system and widespread corruption) came under attack in Western Europe during the carefree 2000s: anti-immigration actions intensified, and populist politicians such as Viktor Orban and Marine Le Pen successfully campaigned using xenophobic rhetoric. Such forces can capitalise on political and social anxieties, especially among those strata that experience transitions, acceptance of European Union norms and regulations and cultural globalisation as a traumatic loss of identity and status. As some countries will join the EU earlier than others, populist ethnocentrism will play on feelings of abandonment, rejection and humiliation among the 'forgotten' nations. And if accession comes, then these countries can easily turn to myth and mobilisation on the manufactured subjection of a let down. This is, for example, one of the pillars of the neo-authoritarian movement in Croatia.

Even in those countries that have 'joined the club', the discussion is not closed regarding the nature of political and national community: will Poland and Hungary accept multiculturalism as a foundation of their new identity, or will they rather favour an Austrian-style model of ethnocultural homogeneity and by implication rejection of the other? At what cost do they insist on their visions? Even if we think of the Czech Republic as one of the most successful cases of democratic transition, there are quite a few alarming trends: the Zeman minority government has stayed in power even though the German conductor from Hamburg hired by the Czech Philharmonic was fired for being German and thus presumably lacking a 'Czech' soul for 'Czech' music. Or remember the notorious walls and violence against Roma as a means to 'solve the Gypsy problem'. Even the Baltic states have bickered over the historical right to folk songs. While seemingly silly and irrelevant, these debates are precisely the kinds of things which can snowball to more serious paranoias.

The Milosevic-style expansionist chauvinism has not been emulated outside the borders of the former Yugoslavia, until Russian imperialism attacked Ukraine. In much of the post-communist world, the landscape is one of disenchantment, uncertainty and cynicism. The initial times of post-communist euphoria are over, and this applies also to the more advanced states in terms of democratic capitalist reforms. Hate and mass violence, like Milosevic unleashed then and Putin now, follow closely behind. Social violence against minorities is high in Hungary and Belarus, and has increased in the United Kingdom and the United States since 2016. For two decades the 
search for new political myths was simply more visible in the East, where all social contrasts were exacerbated and where the breakdown of old identities was more acute. But the phenomenon is worldwide and now intensely powerful in the West as well. Proto-fascist feelings of some malaise and then rage are rising in countries which have little or no baggage or excuses, unlike the troubled lands of Eastern Europe.

There were nine threats in Eastern Europe which made the deification of myth possible, which would eventually enable the triumph of nationalism over democracy: the Leninist debris, the power of magic thinking, remembrance of things not quite past or non-existent, protean politics and the fluidity of political formations, the tyranny of the majority, a crisis of values and authority, a justice-less peace, the weakness of the political class and the democratic ideas it professes and the communitarian versus individual values split. All of these have proved stronger than the tranquillity of successful albeit imperfect democratic societies in Eastern Europe.

The UK has no communist past and Leninist debris, but its population is just as vulnerable to fantasy and myth. If anything, the lack of a communist past like that in Eastern Europe has only made the UK more likely to engage with these social fallacies, as there has been more time to get used to, and then annoyed with, freedom, and there is no memory of the disastrous consequences which inevitable result from straying from tolerance. Myth can work anywhere, and wherever it emerges, hate and tyranny are closely behind.

Other authors in this roundtable have pondered the mystery of Brexit. Some of my colleagues here see British anxieties of globalisation and change, and see how this combined with a distinctly British feeling of being unique and separate from Europe, especially the newer half of the European Union, to make 'independence' seem logical and beneficial. All that can be said is that Dark Times (I insist it is capitalised, it is a real, concrete phenomenon; just ask the victims) come when myth becomes mainstream. Democracy remains the only just system, with human rights as the sole thing of importance in the world. Our task is to understand, not underestimate or dismiss, the vile idiocies growing amidst our populations. We have to advocate politely but fiercely for democracy. Brexit is merely the newest burst of the common experience of myth that always find a way to convince the masses that Perón is the solution. Our job is to expose him for the violent fool and idiotic tyrant he is, to fix our own serious mistakes and to reaffirm that democracy and tolerance are our only choice and chance.

Cordial thanks to Jordan Luber for his thoughtfully enriching editing of my text.

Cite this article: Tismaneanu, V. 2019. What Went Wrong and Why? Nationalism versus Democracy in Eastern and Western Europe. Contemporary European History 28: 69-72, doi: 10.1017/S096077731800084X 